\title{
Small scale migration along the interoceanic highway in Madre de Dios, Peru: an exploration of community perceptions and dynamics due to migration
}

Kelly E Jensen ${ }^{1,2,8^{*}}$ (D), Nehal N. Naik ${ }^{3 \dagger}$, Christina O’Neal ${ }^{1,2 \dagger}$, Gabriela Salmón-Mulanovich ${ }^{4,5}$, Amy R. Riley-Powell ${ }^{2}$, Gwenyth O. Lee ${ }^{2,6}$, Stella M. Hartinger ${ }^{5,7}$, Daniel G. Bausch ${ }^{2,4}$ and Valerie A. Paz-Soldan ${ }^{2,5}$

\begin{abstract}
Background: Madre de Dios, a southern state in the Peruvian Amazon basin, has experienced rapid development as well as an influx of migrants since the construction of the Interoceanic Highway (IOH) connecting Brazil, Bolivia, and the Peruvian coast. We explored perceptions of migration and development in up to eight communities along the $\mathrm{IOH}$ in Madre de Dios following construction of the highway.

Methods: We conducted a multiple methods study involving focus group (FG) discussions and interviews with key informants (KIs) in eight communities in Madre de Dios. The data was used to develop and apply a survey on demographics, financial, personal, social, human, and physical capital in four communities between February 2014 and March 2015.

Results: We conducted $12 \mathrm{FGs}$ and $34 \mathrm{Kl}$ interviews. A total of 522 people participated in the survey. Comparing migrants (those who had moved to the area after construction of the $\mathrm{IOH}$ ) and non-migrants, we found no difference in food security or access to health services. The majority (67.6\%) of respondents from both groups reported that illness was their primary threat to well-being. Non-migrants owned more land than migrants $(p<0.001)$, were more likely to have piped water directly in their home $(p=0.046)$, and were more likely to participate in community groups $(p=0$. 012). Looking at perceptions about migrants, Kls and FGs discussed both positive perceptions of migrants (increased cultural exchange and new technology) and negative perceptions (increased drugs and alcohol in their communities and a lack of investment in the community). Both migrants and non-migrants reported trusting the local government more than the national government.

(Continued on next page)
\end{abstract}

\footnotetext{
* Correspondence: jensenke90@gmail.com

'Equal contributors

${ }^{1} T$ ulane University School of Medicine, 1430 Tulane Ave, New Orleans, LA

70112, USA

${ }^{2}$ Tulane University School of Public Health and Tropical Medicine, 1440 Canal

St, New Orleans, LA 70112, USA

Full list of author information is available at the end of the article
} 
(Continued from previous page)

Conclusions: Although we hypothesized that migrants would have decreased access to food, water, health services, and land relative to non-migrants, our results show that the only significant differences were in land ownership and water access. Efforts to improve community infrastructure should be carried out at the local level and focus on improving issues reported by both groups, such as potable water, sewage, and increased access to health senvices. Furthermore, an emphasis on community cohesion, ensuring land rights, and increasing long-term job opportunities should help ease tensions between migrants and non-migrants.

Keywords: Rural migration, Economic growth and development, Community perceptions

\section{Background}

Madre de Dios, a southern state in the Peruvian Amazon river basin, has been a destination of internal migration since the 1960s, following the construction of the first road into the province [1]. Migration into this area has since increased steadily due to the availability of natural resources such as rubber, Brazil nuts, animal skins, fine wood, and gold. In the 2000s, the province saw a sudden influx of new migrants as a result of the construction of the Interoceanic Highway (IOH) $[1,2]$ and gold mining, much or all of it illegal [3]. The construction of the $\mathrm{IOH}$, which connects the Atlantic ports of Brazil to the Pacific ports of Peru, was part of the Initiative for Integration of Regional Infrastructure in South America to increase cross-border infrastructure and economic development $[1,4]$. Construction began in Brazil in 2002, in Peru in 2006, and was completed in 2011 [2, 5]. Unlike other internal migration movements in Peru, which have generally been rural to urban [6], migration in Madre de Dios has been rural to rural. Migrants are mainly arriving from other parts of the Peruvian Amazon, as well as from the Andean regions of Cusco and Puno which have possible Quechua or Aymara culture and language influences (Fig. 1). It is important to note that Peru is characterized by three distinct geographic regions: the coast, the Andes (mountains), and the rainforest. Although Spanish is considered the national language, each region has distinct characteristics leading to different lifestyles, as well as different indigenous and local groups.

Previous migration studies have focused on the economic rational for migration from rural to urban areas [7] or the capacity of cities to accommodate new migrants [8]. The term "migrant" has no internationally recognized definition [9]. Varying classifications in the literature have included non-native birthplace, citizenship or legal status, or reason for migration $[9,10]$. In Latin America, urbanization is driving economic migration [6]. The construction of the $\mathrm{IOH}$, leading to increased economic opportunities (such as logging or gold mining), is the main driving factor for migration to Madre de Dios. Therefore, in this study we define a migrant as a community member who self-identified as living in the community after the construction of the $\mathrm{IOH}$ began in Peru (equivalent to having moved to the community in or after 2006).

Migrants face many challenges upon relocation, including access to government programs, especially for health care and other public services. Migrants also tend to earn disproportionately lower incomes and shoulder higher economic costs $[11,12]$. Preliminary qualitative data collected by our working group suggested that there was conflict between migrants and non-migrants within the communities in Madre de Dios, leading to a distinction between the two groups, and to our decision to examine this issue further. In Peru, studies such as the PERU MIGRANT project have started to look at health disparities between rural to urban migrants, but little has been done to look at the community as a whole, and few studies examine rural to rural migration, particularly in remote areas of the rainforest, and how this affects the lives of the migrants and the long-term residents $[9,10]$.

The study "Effects of Anthropogenic Habitat Perturbation on Rodent Population Dynamics and Risk of Rodent-Borne Diseases" is a five-year multisite investigation designed to examine the impact of anthropogenic land use on habitat integrity, biodiversity loss, and the risk of rodent-borne diseases [2]. Investigation of community perceptions of changes related to the $\mathrm{IOH}$ were included as part of the study. Here we report on community perceptions of migration in the Madre de Dios region after construction of the $\mathrm{IOH}$ and the issues communities face following rapid development. Findings from this study can be used to inform policy and programmatic interventions to improve local services, infrastructure, and the wellbeing of residents in these rapidly changing communities.

\section{Methods \\ Sampling}

Purposive sampling was used to select communities based on community size, proximity to the $\mathrm{IOH}$, accessibility to Puerto Maldonado, and proximity to communities included in a prior pilot study [13]. Community sizes ranged from 250 to 2500 residents based on 2007 census data [14]. 


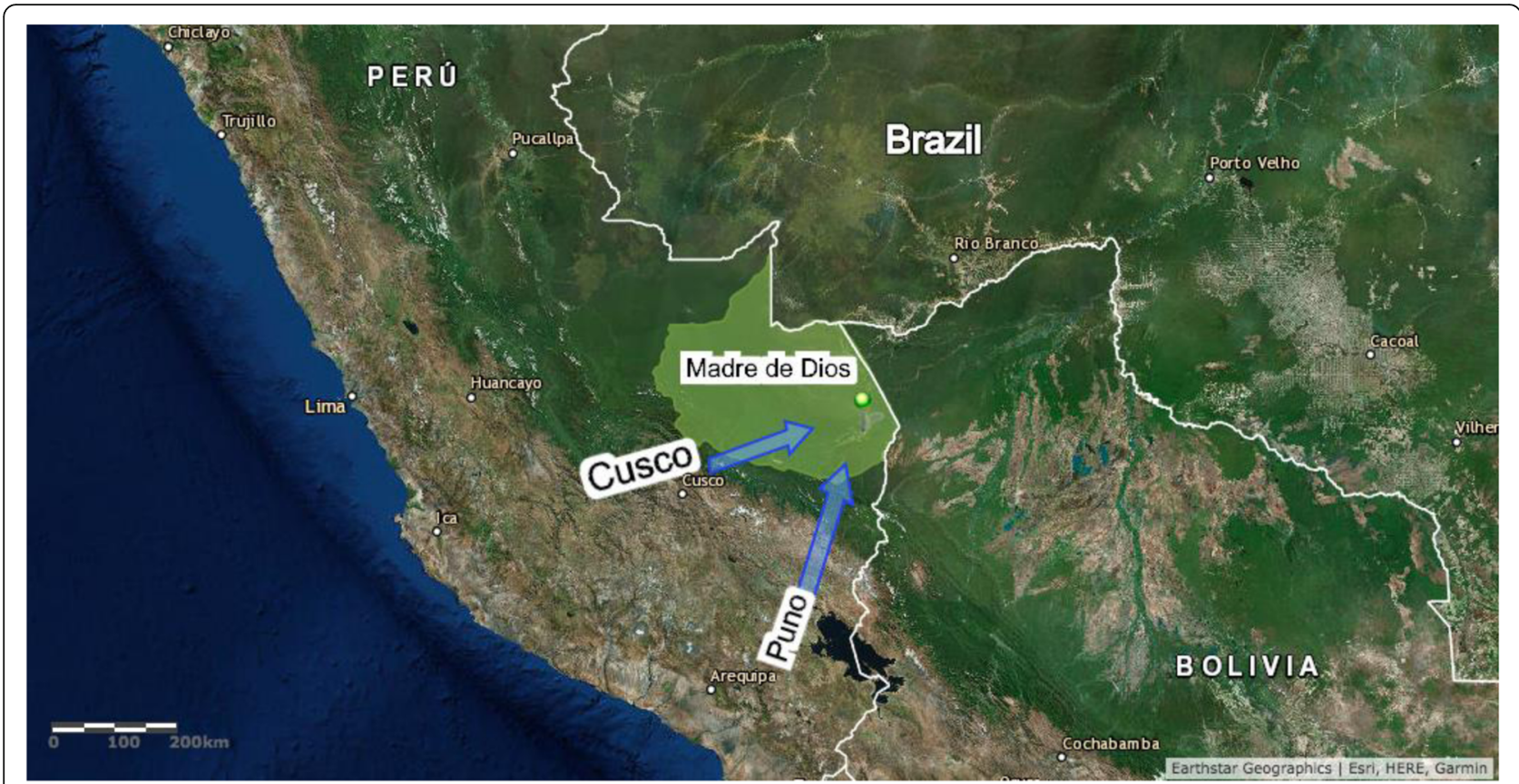

Fig. 1 Map illustrating the major migration patterns to Madre de Dios following the construction of the Interoceanic Highway. Created Using: ArcGIS Online [Internet]. Redlands, CA: Environmental Systems Research Institute (ESRI); Available from: www.esri.com

\section{Study design}

Data collection occurred in two phases: The first phase took place in 2014 and consisted of qualitative methods to explore community member's perspectives of their health and wellbeing. We conducted focus group (FG) discussions and key informant (KI) interviews in eight communities located along the $\mathrm{IOH}$ in Madre de Dios, Peru. Half of the participating communities were northwest of Puerto Maldonado (the Region's capital city) and the other half were southwest of the capital (Fig. 2). The second phase took place in 2015 and comprised the application of a survey, which was developed using data from 2014, and additional KI interviews in four of these communities (two northwest and two southwest of the capital). All qualitative methods continued until saturation - the point at which no new themes are uncovered - was reached [15].

\section{Focus group discussions}

In phase one we used purposive sampling to identify individuals for FG participation. Due to the nature of our data collection (field workers going door to door during the day), our sample was primarily made up of women since, in this region, men tended to be out of the house working during the day. These women were often in charge of managing their household's health and had often been living in the area for over five years. We targeted community members who were able to comment on changes since the construction of the $\mathrm{IOH}$ and influx of new residents. This group included individuals living in the area both before, and around the time, the $\mathrm{IOH}$ was constructed. FG participants were recruited one-totwo days prior to scheduled FG dates through community authorities and the research team. However, due to low attendance rates, additional available individuals in the community were recruited the same day the FG took place. Each FG was facilitated by a trained Peruvian anthropologist with a FG guide used to direct the discussions and included questions about health, well-being, rodents, the $\mathrm{IOH}$, education, safety, and food security. Detailed notes were compiled at the end of each day and FG data were summarized manually and then thematically analyzed with Dedoose software [16] using a grounded theory approach.

\section{Key informant interviews}

All KIs were identified by local collaborators using purposive and snowball sampling: we started by identifying community authorities and health personnel who then suggested other individuals in the community who act in leadership roles. We developed an interview guide that included questions about the community and changes observed within the communities over the past 510 years (Additional file 1). The FG facilitator led the KI interviews in 2014 and another trained researcher conducted the KI interviews in 2015 with an accompanying note taker. We made detailed notes for all interviews. We summarized KI interview data manually and then thematically analyzed the data in 'Dedoose' [16]. Themes are described within the text and quotes used where relevant. 


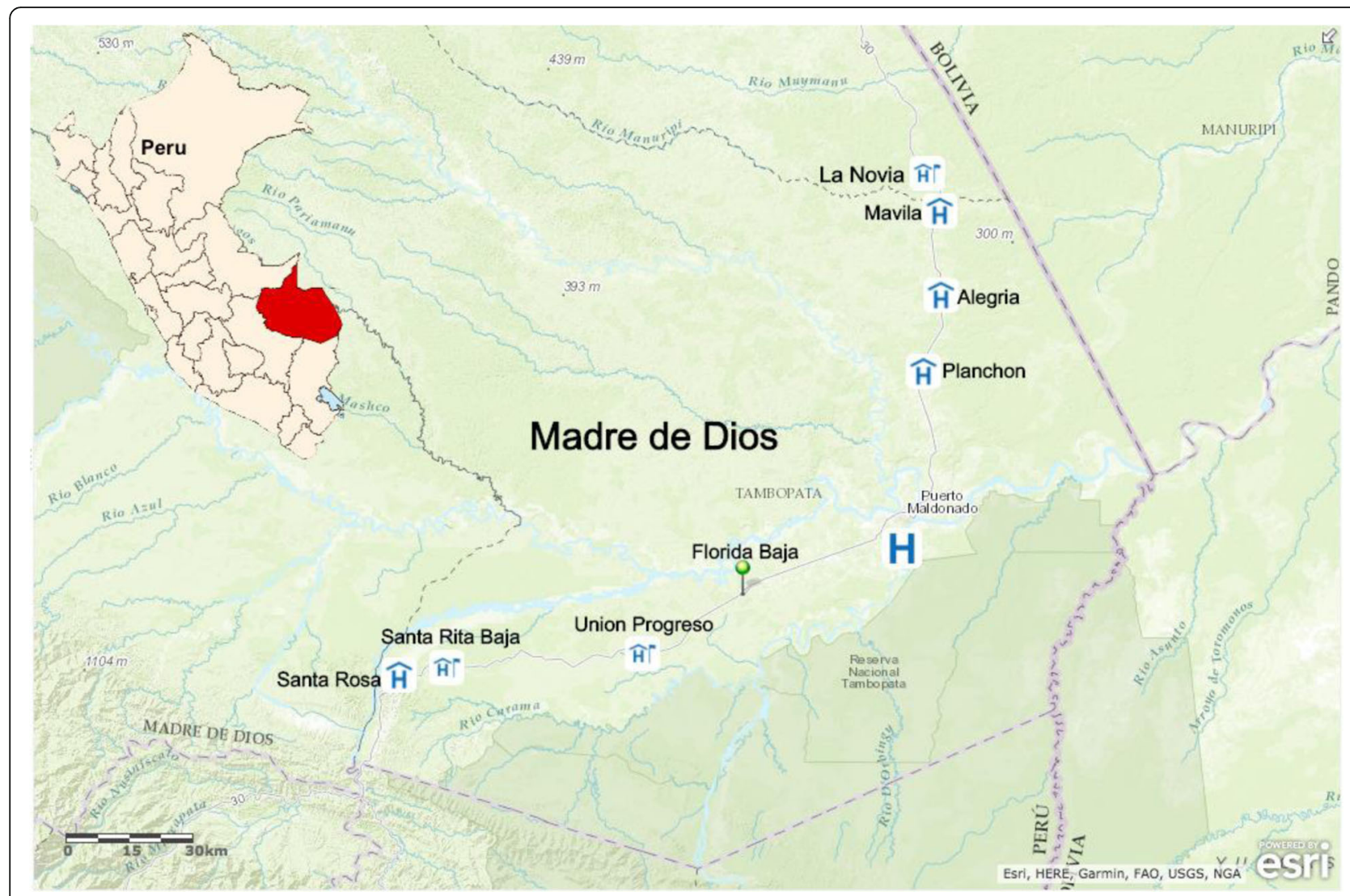

Fig. 2 Map of Madre de Dios and the surrounding eight communities involved in the study. Created Using: ArcGIS Online [Internet]. Redlands, CA: Environmental Systems Research Institute (ESRI); Available from: www.esri.com

\section{Survey}

The survey, conducted in 2015 was comprised of six sections relating to different domains mapping the five forms of capital (financial, personal, social, human, and physical) emphasized in the livelihood approach [17]. This was consistent with themes that were identified in the 2014 qualitative data. We administered the survey door-to-door by trained fieldworkers under the supervision of an experienced field coordinator. Due to controversy about gold mining in Madre de Dios and possible legal repercussions, local authorities and KIs requested that no information about gold mining be elicited during the survey.

\section{Data analysis}

We entered and analyzed survey data using STATA 14.1 [18]. We performed bivariate analysis based on migrant versus non-migrant status using Pearson's chi square test or Fisher's exact test, as required, for categorical variables and independent sample t-test comparing means for continuous variables. We used regression analysis to examine the associations between variables of interest, while controlling for age, sex, and wealth index. We set statistical significance at a two-tailed $p$-value $<0.05$.

\section{Variables}

We developed a wealth index using diverse indicators of financial capital, including housing quality, durable consumer goods, and housing services/utilities as a decimal score between 0 and 100 [19].

\section{Ethics}

The study was approved by the Institutional Review Boards of the US Naval Medical Research Unit No. 6 (NAMRU-6) (NAMRU6.2013.0025), the Universidad Peruana Cayetano Heredia (62162), and Tulane School of Public Health and Tropical Medicine (545719). In addition, we contacted local authorities and community leaders from each study area, who also agreed to provide support. We obtained written informed consent from all participants.

\section{Results}

\section{Focus groups}

We conducted 12 FGs, with participation from a total of 83 community members from eight communities. The majority of FGs were with female participants $(68 \%$ of FG participants were female) due to our experience that: 1) women often participate more when men are not 
present, and 2) in this region, women (primarily mothers) tend to be the ones who manage household illnesses, which were the focus of the study. Due to our interest in exploring life before and after the $\mathrm{IOH}$, ten of the FGs were composed exclusively of long-term residents to explore community changes and historical perceptions. All FG participants were over 18 years old.

\section{Key informant interviews}

We conducted $34 \mathrm{KI}$ interviews with community leaders and healthcare personnel, 21 in February 2014 (between one and four KI interviews in each of the eight communities) and 13 in March 2015 (three to four KI interviews in each of the four communities). No recordings were available from interviews in 2014 and four of the interviewees in 2015 did not consent to be recorded. For KIs who did not consent to recordings (though all consented to study participation), summary notes were used to identify general themes. Transcripts were used from nine KI interviews from March 2015: Santa Rosa, La Novia, Alegría, and Florida Baja $(N=2,2,3$, and 2, respectively). We categorized occupations of KIs into four main groups: elected officials $(N=5)$, health care professionals $(N=2)$, education professionals $(N=1)$, and legal professionals $(N=1)$.

\section{Survey}

A high proportion of houses (41\%) were found to be uninhabited when attempting to apply the survey, 6\% declined participation, and $8 \%$ could not talk to the surveyors at the time of data collection. There were a total of 522 survey respondents, answering on behalf of themselves and the individuals in their homes. Only individual respondent answers were used in this analysis unless otherwise indicated (head of households were asked about threats to health and wellbeing that affected both themselves and their family members). A total of $202(38.7 \%)$ of respondents were defined as nonmigrants and $320(61.3 \%)$ as migrants (Table 1). The average arrival date of migrants in La Novia was in 2010, while in other communities it was around 2012 (Fig. 3). We found significant differences between migrants and non-migrants with regard to age and sex, but not civil status, religion, language, or level of education. Common occupational activities included forestry, agriculture/farming, and commerce. There was no significant difference in occupation type between migrants and non-migrants.

\section{Examining five livelihood capitals, stratified by migrant vs non-migrant}

During exploratory analysis in 2014, the clear-and at times tense-dynamic between more recent and longterm residents was apparent, prompting this analysis.
We explored community perceptions regarding recent migrants more carefully in FG discussions, KI interviews, and surveys conducted in 2015. We used the livelihood capital framework [13] to design questions, as well as to present our findings, stratifying our findings at each level of the livelihood capitals by migrant status to examine any differences. See Tables 2, 3, 4, 5, 6, 7, 8, 9 and 10 for a summary of the findings by subheading within each type of capital.

\section{Physical capital \\ Food access}

We explored food security using three questions from the survey, which assess quantity of food and actions taken to secure food. These were not part of a larger validated scale. The majority of respondents stated that they ate sufficiently (86.8\%), but not always (57.5\%), although $13.2 \%$ reported sometimes or frequently not having enough to eat, with no significant difference between migrants and non-migrants (Table 2). The most common reason for poor food security was insufficient money to purchase food. A higher wealth index was significantly associated with increased food security ( $p=$ 0.001), whereas migrant status was not. Although not statistically significant, almost $10 \%$ more migrants than non-migrants reported that their food supply would run out before they could acquire more. Of the 69 respondents who reported feeling food insecure, the most commonly reported coping strategies were to purchase food from the store on loan or to ration their food. While KIs never discussed food insecurity directly, they did highlight the importance of agriculture as a family's food source. In Florida Baja, agriculture was described as “... for consumption by families." The importance of agriculture as subsistence farming was also brought up in the FGs and described as an additional source of income when necessary.

\section{Water access}

A majority (84.1\%) of all respondents had piped directly into their home for general and drinking use. Significantly more non-migrants had access to piped water directly in their homes than migrants $(p=0.046)$ (Table 3$)$. Most respondents reported treating the water to make it safe to drink (69.0\%), and significantly more migrants treated their water than non-migrants $(p=0.045)$. The primary method to treat water was boiling, with no major difference between groups, followed by a minority who treated with chlorine or bleach. Most KIs reported that their community had a water tank for the population and in some cases for individual households. Whether or not water was treated varied between KIs. A KI from Alegria described the availability of water: "Water ... it is not potable water...it's from a gorge, they 
Table 1 Demographics

\begin{tabular}{|c|c|c|c|c|}
\hline & $\begin{array}{l}\text { Sample } \\
N=522\end{array}$ & $\begin{array}{l}\text { Non-Migrant } \\
N=202\end{array}$ & $\begin{array}{l}\text { Migrant } \\
N=320\end{array}$ & $P$-value \\
\hline Age, mean (SD) & $36.0(0.6)$ & $40.6(1.0)$ & $33.0(0.6)$ & $<0.001$ \\
\hline Female, no. (\%) & $371(71.1 \%)$ & $133(65.8 \%)$ & $238(74.4 \%)$ & 0.036 \\
\hline Civil Status & & & & 0.088 \\
\hline Cohabitating/married & $406(77.8 \%)$ & $151(74.7 \%)$ & $255(79.7 \%)$ & \\
\hline Separated/widowed/divorced & $60(11.5 \%)$ & $31(15.3 \%)$ & $29(9.1 \%)$ & \\
\hline \multirow[t]{2}{*}{ Single } & $56(10.7 \%)$ & $20(9.9 \%)$ & $36(11.3 \%)$ & \\
\hline & $\begin{array}{l}\text { Sample } \\
N=510\end{array}$ & $\begin{array}{l}\text { Non-Migrant } \\
N=196\end{array}$ & $\begin{array}{l}\text { Migrant } \\
N=314\end{array}$ & $P$-value \\
\hline Occupation & & & & 0.203 \\
\hline Forestry & $157(30.8 \%)$ & $63(32.1 \%)$ & $94(29.9 \%)$ & \\
\hline Agriculture/farming & $148(29.0 \%)$ & $47(24.0 \%)$ & $101(32.1 \%)$ & \\
\hline Commerce & $45(8.8 \%)$ & $18(9.2 \%)$ & $27(8.6 \%)$ & \\
\hline Transport & $40(7.8 \%)$ & $15(7.7 \%)$ & $25(8.0 \%)$ & \\
\hline Construction/mechanic & $39(7.7 \%)$ & $13(6.6 \%)$ & $26(8.3 \%)$ & \\
\hline Household activities & $23(4.5 \%)$ & $13(6.6 \%)$ & $10(3.2 \%)$ & \\
\hline Management/professional & $15(2.9 \%)$ & $5(2.5 \%)$ & $10(3.2 \%)$ & \\
\hline Other & 43 (8.4\%) & 22 (11.2\%) & $21(6.7 \%)$ & \\
\hline
\end{tabular}

fill a big tank for your house." When asked where people who do not have access to this source collected water, the KI responded, "there are ravines. People go and collect their water from the ravine, but it is not potable water." A KI from Mavila described the water service in the community saying that sometimes there is no water and when there is, the water is yellow. The KI went on to describe that the community has a tank for everyone and the health center (or municipality) treats the water with chlorine.

\section{Human capital}

\section{Health and wellbeing}

A vast majority of respondents $(86.1 \%)$ did seek treatment or advice from the nearest health facility when they had illnesses, with no differences between migrants and non-migrants (Table 4). Of those who sought treatment, most went to public health facilities (public hospital or health center/post). Only two people reported self-medicating, both of whom were non-migrants.

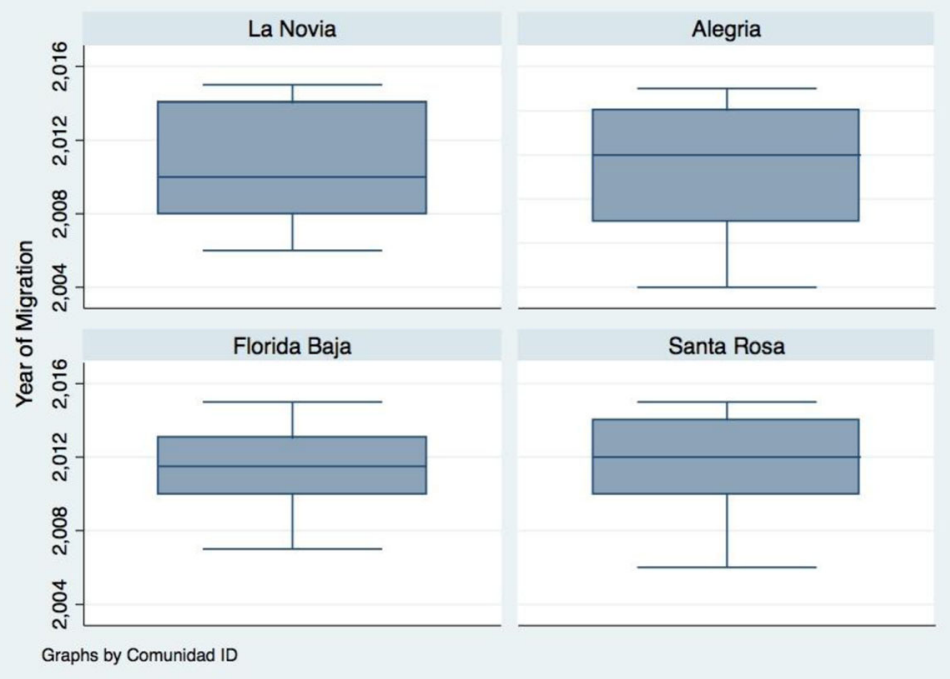

Fig. 3 Comparison of arrival date by community for migrants arriving between 2000 and 2015 
Table 2 Physical capital: Food access

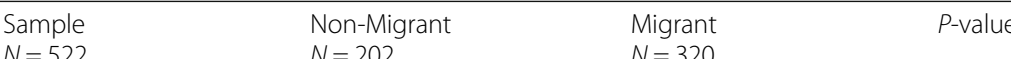

Describe the food situation at home in the last 12 months:

\begin{abstract}
We always eat sufficiently
Eat sufficiently, but not always

Sometimes we do not eat sufficiently

Frequently we do not eat sufficiently
\end{abstract}

\footnotetext{
I do not have enough money for food

Other
}

$$
\begin{aligned}
& 153(29.3 \%) \\
& 300(57.5 \%) \\
& 58(11.1 \%) \\
& 11(2.1 \%) \\
& \text { Sample } \\
& N=69
\end{aligned}
$$

$60(87.0 \%)$
$N=202$

$60(29.7 \%)$
$123(60.9 \%)$
$16(7.9 \%)$
$3(1.5 \%)$
Non-Migrant
$N=19$

$60(29.7 \%)$

$N=19$

$16(84.2 \%)$

$3(15.8 \%)$
0.239

$93(29.1 \%)$
$177(55.3 \%)$
$42(13.1 \%)$
$8(2.5 \%)$
Migrant
$N=50$

\begin{tabular}{|c|c|c|c|}
\hline Never & $10(14.5 \%)$ & $4(21.1 \%)$ & $6(12.0 \%)$ \\
\hline Total Yes & $59(85.5 \%)$ & $15(78.9 \%)$ & $44(88.0 \%)$ \\
\hline Yes - rarely/sometimes & $34(49.3 \%)$ & $7(36.8 \%)$ & $27(54.0 \%)$ \\
\hline Yes - frequently/always & $25(36.2 \%)$ & $8(42.1 \%)$ & $17(34.0 \%)$ \\
\hline \multicolumn{4}{|l|}{ Reaction to insufficient food at home: } \\
\hline Get a loan from a store, family or friends & $37(53.6 \%)$ & $9(47.4 \%)$ & $28(56.0 \%)$ \\
\hline Reduce rations or not eat & $23(33.3 \%)$ & $6(31.6 \%)$ & $17(34.0 \%)$ \\
\hline Other & $9(13.1 \%)$ & $4(21.0 \%)$ & $5(10.0 \%)$ \\
\hline
\end{tabular}

P-value 0.699

$44(88.0 \%)$

$6(12.0 \%)$

Worried about running out of food before you can acquire more during the last 12 months:

Additionally non-migrants were significantly more likely to pay for their treatment than migrants ( $p=$ $0.004)$. Notably, migrants lived significantly closer to their medical treatment site than non-migrants; the majority (54.4\%) of migrants reported living less than 30 min away $(p=0.008)$. Less than $10 \%$ of all respondents reported going to herbalists or traditional 'curanderos', with no significant difference between groups. However, the topic of traditional medicine came up in FGs, during which participants reported that coconut water was used as a treatment for both malaria and dengue.

Respondents were asked about the greatest threat to the well-being of each individual member of their

\begin{tabular}{|c|c|c|c|c|}
\hline & $\begin{array}{l}\text { Sample } \\
N=522\end{array}$ & $\begin{array}{l}\text { Non-Migrant } \\
N=202\end{array}$ & $\begin{array}{l}\text { Migrant } \\
N=320\end{array}$ & $P$-value \\
\hline \multicolumn{4}{|l|}{ Primary water supply for family: } & 0.046 \\
\hline Tubed/piped water source & $439(84.1 \%)$ & $178(88.1 \%)$ & $261(81.6 \%)$ & \\
\hline Open/natural water source & $83(15.9 \%)$ & $24(11.9 \%)$ & $59(18.4 \%)$ & \\
\hline \multicolumn{4}{|c|}{ Primary drinking water source for family: } & 0.020 \\
\hline Tubed/piped water source & $441(84.5 \%)$ & $180(89.1 \%)$ & $261(81.6 \%)$ & \\
\hline Open/natural water source & $81(15.5 \%)$ & $22(10.9 \%)$ & $59(18.4 \%)$ & \\
\hline \multicolumn{4}{|c|}{ Treat water to make it safer to drink: } & 0.045 \\
\hline Yes & $360(69.0 \%)$ & $129(63.9 \%)$ & $231(72.2 \%)$ & \\
\hline \multicolumn{4}{|c|}{ Method used to treat water to make it safer to drink: } & 0.200 \\
\hline Boil the water & $295(56.5 \%)$ & $108(53.5 \%)$ & $187(58.5 \%)$ & \\
\hline Chlorine/Bleach & $62(11.9 \%)$ & $20(9.9 \%)$ & $42(13.1 \%)$ & \\
\hline None & $162(31.0 \%)$ & $73(36.1 \%)$ & 89 (27.8\%) & \\
\hline Other & $3(0.6 \%)$ & $1(0.5 \%)$ & $2(0.6 \%)$ & \\
\hline
\end{tabular}
household by age group. The greatest reported threat was illness (Table 5). When asked about the greatest threats to well-being, $67.6 \%$ of respondents thought illness was the greatest threat to themselves and their

Table 3 Physical capital: Water access 
Table 4 Human capital: Wellbeing

$\begin{array}{llll}\text { Total } & \text { Non-Migrant } & \text { Migrant } & P \text {-value } \\ N=237 & N=97 & N=140 & \end{array}$

Seek treatment or advice when you have an illness:

\begin{tabular}{|c|c|c|c|c|}
\hline Yes & $204(86.1 \%)$ & $78(80.4 \%)$ & $126(90.0 \%)$ & \\
\hline If YES: & & & & 0.189 \\
\hline \multicolumn{5}{|l|}{ Treatment site: } \\
\hline Public health services & $165(80.9 \%)$ & $61(78.2 \%)$ & $104(82.5 \%)$ & \\
\hline Private health services & $21(10.3 \%)$ & $12(15.4 \%)$ & $9(7.2 \%)$ & \\
\hline Non-regulated health services & $18(8.8 \%)$ & $5(6.4 \%)$ & $13(10.3 \%)$ & \\
\hline Pay for any treatment: & & & & 0.004 \\
\hline \multirow[t]{2}{*}{ Yes } & $113(55.4 \%)$ & $54(69.2 \%)$ & $59(46.8 \%)$ & \\
\hline & $\begin{array}{l}\text { Total } \\
N=203\end{array}$ & $\begin{array}{l}\text { Non-migrant } \\
N=74\end{array}$ & $\begin{array}{l}\text { Migrant } \\
N=129\end{array}$ & $P$-value \\
\hline Distance from home to treatment site: & & & & 0.008 \\
\hline Less than 30 min & $92(45.3 \%)$ & $24(30.8 \%)$ & $68(54.4 \%)$ & \\
\hline Less than $1 \mathrm{~h}$ & $30(14.8 \%)$ & $13(16.7 \%)$ & $17(13.6 \%)$ & \\
\hline Less than $2 \mathrm{~h}$ & $29(14.3 \%)$ & $13(16.7 \%)$ & $16(12.8 \%)$ & \\
\hline More than $2 \mathrm{~h}$ & $52(25.6 \%)$ & $28(35.9 \%)$ & $27(19.2 \%)$ & \\
\hline
\end{tabular}

families followed by injury. There was a significant difference between migrants and non-migrants ( $p=$ 0.040 ) with more non-migrants reporting drugs and alcohol as threats to wellbeing.

The theme of delinquency and use of alcohol and drugs arose during a few interviews, with several KIs attributing increasing delinquency to migrants (not supported in surveys) and to the $\mathrm{IOH}$ construction in general. A KI from Alegria stated "Something that isn't a benefit [to the community] is the presence of migrants. Suddenly there was delinquency... Cantinas [bars] have increased, and there are people not from here that have money and drink frequently. There is prostitution [and] alcoholism." Another KI from Santa Rosa complained, "I'm in the middle of it now; drugs and alcohol every day... [the $\mathrm{IOH}$ has brought us] negative things like theft, the problem of alcoholism, drugs, and prostitution."

Table 5 Personal capital: Threats to health and wellbeing

\begin{tabular}{lllll}
\hline & $\begin{array}{l}\text { Total } \\
(n=1265)^{*}\end{array}$ & $\begin{array}{l}\text { Non-migrant } \\
(n=493)\end{array}$ & $\begin{array}{l}\text { Migrant } \\
(n=772)\end{array}$ & P-Value \\
\hline Principal threat to the health and wellbeing of the family & 0.040 \\
Illness & $855(67.6 \%)$ & $322(65.3 \%)$ & $533(69.0 \%)$ & \\
Injuries/Accidents & $199(15.7 \%)$ & $74(15.0 \%)$ & $125(16.2 \%)$ & \\
Poor Hygiene/Nutrition & $96(7.8 \%)$ & $40(8.1 \%)$ & $58(7.5 \%)$ & \\
Drugs/Alcohol & $49(3.9 \%)$ & $29(5.9 \%)$ & $20(2.6 \%)$ & \\
Other & $64(5.0 \%)$ & $28(5.7 \%)$ & $36(4.6 \%)$ & \\
\hline
\end{tabular}

*Head of household answered for themselves and their family members

\section{Financial capital}

\section{Land ownership}

As might be expected, migrants were more likely to own less land than non-migrants, with $75.4 \%$ of migrants owning less than one hectare, while nearly a third (28.4\%) of non-migrants owned more than 20 ha (Table 6). On average, migrants owned significantly fewer hectares than non-migrants $(p<0.001)$.

One theme that came up during KI interviews, which was not explored in the survey, was the lack of land security. A KI from Florida Baja commented, "We don't feel safe because this land was sold [without guarantee] to me, so we don't feel safe in it." This was also reflected in FGs during which several community members reported that their community would be better if their property rights were recognized by the government.

\section{Wealth}

A small but significant difference was found between the wealth index of migrants and non-migrants, where the mean wealth score was lower for migrants

Table 6 Financial capital: Land ownership

\begin{tabular}{lllll}
\hline & $\begin{array}{l}\text { Total } \\
(N=518)\end{array}$ & $\begin{array}{l}\text { Non-Migrant } \\
(N=201)\end{array}$ & $\begin{array}{l}\text { Migrant } \\
(N=317)\end{array}$ & P-Value \\
\hline Hectares of land owned: & & & $<0.001$ \\
Less than 1 & $355(68.5 \%)$ & $116(57.7 \%)$ & $239(75.4 \%)$ & \\
1 to 10 & $43(8.3 \%)$ & $9(4.5 \%)$ & $34(10.7 \%)$ & \\
11 to 20 & $42(8.1 \%)$ & $19(9.4 \%)$ & $23(7.3 \%)$ & \\
More than 20 & $78(15.1 \%)$ & $57(28.4 \%)$ & $21(6.6 \%)$ & \\
\hline
\end{tabular}


Table 7 Personal capital: Safety and threats to security/wellbeing

\begin{tabular}{lcccc}
\hline $\begin{array}{l}\text { Sample } \\
(N=522)\end{array}$ & $\begin{array}{c}\text { Non-Migrant } \\
(N=202)\end{array}$ & $\begin{array}{l}\text { Migrant } \\
(N=320)\end{array}$ & $P$-value \\
\hline Feel safe in your community: & & 0.211 \\
Yes $\quad 329(63.0 \%)$ & $132(65.3 \%)$ & $197(61.6 \%)$ & \\
Feel more exposed to insecurity in the last 5 years: & $<0.001$ \\
Yes $\quad 303(58.0 \%)$ & $131(64.9 \%)$ & $172(53.8 \%)$ & \\
Taken additional security measures: & & 0.051 \\
Yes $\quad 136(26.1 \%)$ & $62(30.7 \%)$ & $74(23.1 \%)$ & \\
\hline
\end{tabular}

than non-migrants (42.6 [95\% CI: 41.5 to 43.7] vs. 47.9 [95\% CI: 4.8 to 49.0 ], respectively; $p<0.0001$ ).

\section{Personal capital}

\section{Safety}

Overall, 63.0\% of survey respondents reported feeling safe in their community, with no significant differences reported between migrants and non-migrants (Table 7). Interestingly, when asked about feeling more exposed to insecurity in their community in the last 5 years, a majority $(58.0 \%)$ of both migrants and non-migrants reported increased insecurity, the timing of which coincides with when migration into the region began. However significantly more non-migrants than migrants reported feeling more exposed to insecurity within the past 5 years $(p<$ 0.001 ). When asked if they had taken any additional security measures there was an almost significant difference between migrants and non-migrants $(p=0.051)$ however only $26.1 \%$ of the entire sample answered that they had employed additional security measures.

Increased feelings of insecurity have resulted in some communities coming together to form "safety committees" in which citizens comprise a neighborhood watch. A KI from Santa Rosa stated, "We have organized our own committee for citizen's security." One KI from Florida Baja explained that in their community, committees are formed by a group of neighbors, in this specific case by 14 members, who alternate shifts to provide 24-h coverage. All are volunteers and work with the intent of preventing crime, as "sometimes there are those who don't know how to respect others' things, and they rob them, but [now] there is a citizens' security committee." Only a small a minority (18\%) of all residents participated in community groups, with significantly different representation of migrants and non-migrants in community organizations (14.4\% vs. $23.2 \%$ respectively, $p=0.012)$.

\section{Social capital \\ Reasons for migration}

In addition to the population of self-identified migrants, any people who were not born in the communities were also asked about their reasons for migration prior to construction of the $\mathrm{IOH}$. The most commonly reported reasons for migrating to Madre de Dios were improved work opportunities and access to land for themselves or their family, followed by improved life conditions (Table 8). Work was also the most commonly reported reason for wanting to stay in the area (Table 9). Related to how well migrants feel integrated into their new home, significantly fewer migrants had their document of national identification (known locally as DNI; an identification that allows them to access state public services more easily within the documented region) assigned to their current location than non-migrants $(p<0.001)$. This was also reflected in the KI interviews, with one KI from Florida Baja stating that migrants "do not have their DNI here. They are migrants from the mountains/sierra."

FGs, KI interviews, and survey data collectively revealed a mix of positive and negative perceptions towards migrants. The majority of non-migrant survey respondents felt that the presence of migrants had made their community worse $(58.7 \%$ said migrants made it

Table 8 Social capital: Reasons for migration

\begin{tabular}{|c|c|c|c|c|}
\hline & $\begin{array}{l}\text { Sample } \\
(N=461)^{*}\end{array}$ & $\begin{array}{l}\text { Non-Migrant } \\
(N=144)\end{array}$ & $\begin{array}{l}\text { Migrant } \\
(N=317)\end{array}$ & $P$-value \\
\hline Reason for moving here: & & & & $<0.001$ \\
\hline More work opportunities/land access (self or family) & $358(77.7 \%)$ & $94(65.3 \%)$ & $264(83.3 \%)$ & \\
\hline Better life conditions (location/family presence) & $73(15.8 \%)$ & $32(22.2 \%)$ & $41(12.9 \%)$ & \\
\hline \multirow[t]{2}{*}{ Other } & $30(6.5 \%)$ & $18(12.5 \%)$ & $12(3.8 \%)$ & \\
\hline & $\begin{array}{l}\text { Sample } \\
(N=465)^{*}\end{array}$ & $\begin{array}{l}\text { Non-Migrant } \\
(N=145)\end{array}$ & $\begin{array}{l}\text { Migrant } \\
(N=320)\end{array}$ & $P$-value \\
\hline Moved with: & & & & $<0.001$ \\
\hline With partner/family & $329(70.8 \%)$ & $75(51.7 \%)$ & $254(79.4 \%)$ & \\
\hline Alone & $94(20.2 \%)$ & $46(31.7 \%)$ & $48(15.0 \%)$ & \\
\hline With friends & $16(3.4 \%)$ & $9(6.2 \%)$ & $7(2.2 \%)$ & \\
\hline Other & $26(5.6 \%)$ & $15(10.4 \%)$ & $11(3.4 \%)$ & \\
\hline
\end{tabular}

*Answered if not born in region 
Table 9 Social Capital: Reasons to stay

\begin{tabular}{|c|c|c|c|c|}
\hline & $\begin{array}{l}\text { Sample } \\
(N=522)\end{array}$ & $\begin{array}{l}\text { Non-Migrant } \\
(N=202)\end{array}$ & $\begin{array}{l}\text { Migrant } \\
(N=320)\end{array}$ & $P$-value \\
\hline \multicolumn{4}{|l|}{ Motivation to stay: } & $<0.001$ \\
\hline Work & $319(61.1 \%)$ & $84(41.6 \%)$ & $235(73.5 \%)$ & \\
\hline Family lives here & $104(20.0 \%)$ & 69 (34.2\%) & $35(10.9 \%)$ & \\
\hline I have land here & $56(10.7 \%)$ & $30(14.8 \%)$ & $26(8.1 \%)$ & \\
\hline Other & $43(8.2 \%)$ & $19(9.4 \%)$ & $24(7.5 \%)$ & \\
\hline \multicolumn{4}{|c|}{ Think you'll bring more people here: } & 0.063 \\
\hline Yes & $90(17.2 \%)$ & $27(13.4 \%)$ & $63(19.7 \%)$ & \\
\hline \multicolumn{4}{|l|}{ Live here all year: } & 0.246 \\
\hline Yes & $502(96.2 \%)$ & $197(97.5 \%)$ & $305(95.3 \%)$ & \\
\hline \multicolumn{4}{|c|}{ Length of time you think you'll stay here: } & $<0.001$ \\
\hline $1-5$ years & $168(32.2 \%)$ & $37(18.3 \%)$ & $131(40.9 \%)$ & \\
\hline $6-20$ years & $74(14.2 \%)$ & $25(12.4 \%)$ & $49(15.3 \%)$ & \\
\hline Always & $280(53.6 \%)$ & $140(69.3 \%)$ & $140(43.8 \%)$ & \\
\hline \multicolumn{4}{|l|}{ DNI listed as here: } & $<0.001$ \\
\hline Yes & $334(64.0 \%)$ & $182(90.1 \%)$ & $152(47.5 \%)$ & \\
\hline
\end{tabular}

worse, $19.4 \%$ same, $21.9 \%$ better). In KI interviews and FGs, perceptions about the impact of migrants on the community were more varied. Migrants were described as having positive impacts on the community, including increased work opportunities and food availability. One KI from Alegria described the positive contributions of migrants as bringing "their culture, [and] new technology for work" to the community. However, some KI and FG participants reported increased problems with drugs and alcohol in their communities, associated with the arrival of migrants. Additionally, a third of KIs felt that migrants were not as invested in their community as local

Table 10 Perceptions of community administration

\begin{tabular}{|c|c|c|c|c|}
\hline & $\begin{array}{l}\text { Sample } \\
N=522\end{array}$ & $\begin{array}{l}\text { Non-Migrant } \\
N=202\end{array}$ & $\begin{array}{l}\text { Migrant } \\
N=320\end{array}$ & $P$-value \\
\hline Decision makers in the community: & & & & 0.012 \\
\hline Local/regional authorities & $416(79.7 \%)$ & $161(79.7 \%)$ & $255(79.7 \%)$ & \\
\hline Everyone (voting) & $62(11.9 \%)$ & $30(14.8 \%)$ & $32(10.0 \%)$ & \\
\hline Local leaders (organizations/households) & $12(2.3 \%)$ & $6(3.0 \%)$ & $6(1.9 \%)$ & \\
\hline Does not know & $32(6.1 \%)$ & $5(2.5 \%)$ & $27(8.4 \%)$ & \\
\hline Local leaders are corrupt: & & & & $<0.001$ \\
\hline Yes & $219(42.0 \%)$ & $103(51.0 \%)$ & $116(36.3 \%)$ & \\
\hline Does not know & $155(29.7 \%)$ & $35(17.3 \%)$ & $120(37.5 \%)$ & \\
\hline Regional leaders are corrupt: & & & & 0.012 \\
\hline Yes & $304(58.2 \%)$ & $134(66.3 \%)$ & $170(53.1 \%)$ & \\
\hline Does not know & $166(31.8 \%)$ & $52(25.7 \%)$ & $114(35.6 \%)$ & \\
\hline National leaders are corrupt: & & & & 0.223 \\
\hline Yes & $376(72.0 \%)$ & $154(76.2 \%)$ & $222(69.4 \%)$ & \\
\hline Does not know & $110(21.1 \%)$ & $37(18.3 \%)$ & $73(22.8 \%)$ & \\
\hline Your opinion matters, and to whom: & & & & $<0.001$ \\
\hline No & $172(32.9 \%)$ & $46(22.8 \%)$ & $126(39.4 \%)$ & \\
\hline Yes, to my neighbors & $111(21.3 \%)$ & $45(22.3 \%)$ & $64(20.0 \%)$ & \\
\hline Yes, to authorities/local leaders & $177(33.9 \%)$ & $98(48.5 \%)$ & 79 (24.7\%) & \\
\hline Does not know & $62(11.9 \%)$ & $13(6.4)$ & 49 (15.3\%) & \\
\hline
\end{tabular}


residents and therefore did not take enough care of the land or participate in the community. Another KI from Alegria summarized the mixed perceptions of migrants as, "On one hand they bring work for the population, and on the other hand, they take advantage of the population... They are businessmen that come with their money and take advantage of the humble people to buy their wood and Brazil nuts."

\section{Governance}

In the survey, we asked participants which level of leadership made decisions that affected their lives. The vast majority of survey respondents thought that local and regional authorities made decisions in the community, with no differences between non-migrants and migrants (Table 10). A notable minority of respondents felt that everyone was able to make decisions through the popular vote $(11.9 \%)$. Overall, there was a significant difference between what migrants and non-migrants reported regarding which level of leadership made decisions affecting their lives $(p=0.012)$; however this was because more migrants than non-migrants reported not knowing who made the decisions. Comparing local, regional and national levels of government, respondents perceived higher levels of corruption in national leaders. The majority of respondents $(72.0 \%)$ believed national leaders were corrupt compared to only $42.0 \%$ of respondents who believed local leaders were corrupt. Similar trends were seen for non-migrants and migrants although significantly more non-migrants believed local leaders and regional leaders were corrupt $(p<0.001$ and $\mathrm{p}=0.012$ respectively). Almost a third of respondents felt their opinions did not matter, while another third felt that authorities cared about their opinion. There were significant differences between migrants and non-migrants, with migrants more often feeling their opinions did not matter $(p<0.001)$. One KI from Santa Rosa described the negative aspects of her community saying, "...we are forgotten by the [national] government and we are trapped in terms of management."

\section{Discussion}

In this study, we defined migrants as individuals who self-identified in the survey as immigrants to the study community after the construction of the $\mathrm{IOH}$ - which began around 2006. Looking at when migrants moved to Madre de Dios, the largest waves of migration occurred after 2007 after the construction of the $\mathrm{IOH}$ had begun. This definition allowed us to examine perceptions of changes in the community associated with the construction of the IOH and the influx of migrants.

Poverty and decreased food access have been well documented in the literature [20-22]. However, in our study there was not a significant difference in access to food between migrants and non-migrants. We posit that, with the infrastructure growth due to the $\mathrm{IOH}$, there was improved distribution of food in the region, decreasing issues of food access. Reduced rates of malnutrition have been reported in urban areas, suggesting that the $\mathrm{IOH}$ may have brought an influx of goods to Madre de Dios similar to, but on a smaller scale, than that seen in urban areas [23].

There was a significant difference in access to water, with more non-migrants having water available directly in their homes. However, direct water does not imply access to potable water. Currently there is a lack of widespread potable water in Peru, highlighting the need for government efforts to increase access to clean drinking water [24]. Access to potable water can be increased by improving household water storage and treatment which has been shown to improve water quality in low resource settings [25]. This would help decrease the threat of illness, which the majority of our participants reported as their primary threat to well-being. Improved water, sanitation, hygiene, and treatment of water with flocculant disinfectant are strongly associated with reductions in diarrheal illnesses, which are a major cause of morbidity and mortality in children under five [20, 26-28]. Interventions should focus on providing covered water vessels and educating community members on safe water treatment and storage [25].

Health access was not significantly different between groups, although migrants lived significantly closer to their point of healthcare. We posit that migrants may have moved to larger population centers due to increased economic opportunities and medical treatment sites are concentrated in these areas. We did note that many migrants had not changed their local identification card (DNI) address to their current one, and there were some misperceptions that they might not be able to access local health care. However, the results did not suggest that migrants had decreased access to health services because of this. That said, it is important to inform the communities that the public health facilities can see any patient needing assistance, not only those registered in the community. As a majority of the community feels illness is a primary threat to wellbeing, health interventions have the potential to greatly improve perceived quality of life for both migrants and non-migrants.

Various results point to the need for strengthening leadership and community capacity building in these areas. This would improve cohesion and land ownership, promote equal job opportunities, and increase the community's involvement in their own citizen run safety committees to address real or perceived security issues. Other studies have discussed some of the challenges increased migration poses on communities, including job 
competition and social turmoil [29]. A study examining outward migration from rural towns in Australia posited that community self-help alone is simply not enough in these areas, and that governmental support of infrastructure, education, and employment are likely the best way to support rural growth [30]. Increasing public, private, and third party investment in growing rural communities may help improve transportation and communications, promote education and training, and create year-round meaningful employment. These macrolevel changes along with the active participation of rural communities could help communities adjust to economic change and positively influence the perception of migrants as they take on a vital role in community development.

Although migrants participated significantly less in community organizations, there was minimal participation by both migrants and non-migrants in community groups. Therefore efforts to improve community integration could focus on increasing civic participation for all community members as this may provide a common meeting place and help decrease the conflict between migrants and long-term residents. Moreover, many community members, particularly migrants, lack proper/official land ownership, which likely also affects their willingness to participate in organizations. Securing land rights can often be effected through community-based land adjudication and registration, rather than expensive national programs [31, 32].

Key informants and FG participants both expressed a sense of abandonment by the national government, which may also contribute to the perception of corruption among national leaders. Survey respondents felt that local leaders were less corrupt than national leaders, suggesting the communities may be more receptive to changes from the local vs. national government. One application of this study could be to focus on future policy changes at the community level and encourage local leaders to be facilitators in order to increase community acceptance and decrease mistrust. One other study has reported perceived corruption among government leaders in Peru, although this was in relation to mining activities [5]. This study reported frustration with the limited capacity of the national and regional government to control illegal mining and foster positive feelings towards community-based conservation efforts. One reason for national government ineffectiveness proposed by a KI was the perception that lawmakers in Lima were unaware of the situation in Madre de Dios and, as a result, they pass ineffective and unenforceable laws.

There are several limitations to this study. First, this study was not designed to focus on the issue of migrants vs. long-term residents, but this topic emerged through the qualitative work. While we explored community perceptions of migrants, the voice of migrants themselves is limited, particularly in the qualitative work. The KI interviews took place with community leaders and FGs were preferentially oriented toward mothers who had lived in the community for more than five years. Due to sampling techniques key informants tended to provide introductions to other longer-term residents. As mentioned previously, the migrant and the non-migrant groups tended not to mix and as a result the voices of migrants are limited. Migrants were also more likely to be working during the day and therefore we were often unable to invite them to participate. Additionally, due to the sensitivities about illegal mining in Madre de Dios, it was sometimes difficult to find KIs willing to be interviewed and recorded, suggesting some bias in the selection of KIs. With regards to the survey, the high number of abandoned or closed houses could be a reflection of high rates of seasonal migration in these communities, which may have further contributed to the lack of migrant's voices in this paper.

\section{Conclusions}

Our study results suggest that efforts to improve communities affected by the $\mathrm{IOH}$ should not focus on migrants and non-migrants but rather the issues reported by both groups. More similarities than differences between the migrant and non-migrant groups suggest a higher level of community integration in terms of experience than is perceived. The possible applications of this research include improving access to potable water in homes as well as health services in this region, which would help ameliorate a key threat to the health and well-being reported by residents in these communities. Since there is more confidence in local leaders than the national government, changes may be best implemented by local leaders. Some of the issues to start improving include fostering community cohesion through participation in organizations, ensuring land rights, and increasing job opportunities, which could begin to break down the perceived barriers between migrant and non-migrant residents in Madre de Dios.

\section{Additional file}

\section{Additional file 1: Interview guide: Questions for key informants.} (DOCX $83 \mathrm{~kb}$ )

\section{Abbreviations}

FG: Focus group; IOH: Interoceanic highway; KI: Key informant

\section{Acknowledgements}

This project would not have been possible without the support from Karina Roman, Lara Schwartz, Valerie Baquerizo, Shelah Centeno, Elvira Morales and the NAMRU-6 Zoonotic Disease Unit. Hector Verástegui provided valuable support with data management. We would also like to thank all the members of the communities for their participation and for taking the time to share their opinions with us. 


\section{Funding}

This work was carried out with the aid of a grant from the Inter-American Institute for Global Change Research (IAI) CRN3076, which is supported by the US National Science Foundation (Grant GEO-1128040). This work was supported by the National Institutes of Health Office of the Director, Fogarty International Center, Office of AIDS Research, National Cancer Center, National Heart, Blood, and Lung Institute, and the NIH Office of Research for Women's Health through the Fogarty Global Health Fellows Program Consortium comprised of the University of North Carolina, John Hopkins, Morehouse and Tulane (R25TW009340). Kelly Jensen was also supported by the Fulbright-Fogarty Fellowship for Peru.

\section{Availability of data and materials}

The datasets generated and analyzed during the current study are not publicly available due to the political situation in Madre de Dios, Peru and the need to protect participant privacy.

\section{Copyright statement}

Some authors are military service members and employees of the U.S. Government This work was prepared as part of their official duties. Title 17 U.S.C. \$105 provides that "Copyright protection under this title is not available for any work of the United States Government". Title 17 U.S.C. §101 defines a U.S. Government work as a work prepared by a military service member or employee of the U.S. Government as part of that person's official duties.

\section{Disclaimer}

The views expressed in this article are those of the authors and do not necessarily reflect the official policy or position of the Department of the Navy, Department of Defense, or the U.S. Government.

\section{Authors' contributions}

$\mathrm{KJ}$ and $\mathrm{CO}$ analyzed and interpreted the qualitative data, and led the development and writing of the manuscript. NN analyzed and interpreted the quantitative data and also led the development and writing of the manuscript. AP was involved in study design including the development of interview guides and survey materials, data collection, and writing and reviewing the manuscript. GSM was involved in study design, interpretation of results, and guiding the development and revision of the final manuscript. GOL was involved in data analysis, data interpretation, and manuscript development. SH was involved in study design and development of study materials. DGB was involved in the initial study design, development and implementation, overseeing the development of the entire study and the revision of this manuscript. VPS was involved in study design, development, project oversight, and development and revision of the final manuscript. All authors read and approved the final manuscript.

\section{Ethics approval and consent to participate}

The study protocol was approved by the U.S. Naval Medical Research Unit No.6 (NAMRU-6) institutional review board (IRB) (protocol number NMRCD.2013.0020), the Universidad Peruana Cayetano Heredia IRB (registration number 62162) and Tulane University IRB (protocol number 545719) in compliance with all applicable federal regulations governing the protection of human subjects. Written consent from obtained from all participants.

\section{Consent for publication}

\section{Not Applicable}

\section{Competing interests}

The authors declare that they have no competing interests.

\section{Publisher's Note}

Springer Nature remains neutral with regard to jurisdictional claims in published maps and institutional affiliations.

\section{Author details}

${ }^{1}$ Tulane University School of Medicine, 1430 Tulane Ave, New Orleans, LA 70112, USA. ${ }^{2}$ Tulane University School of Public Health and Tropical Medicine, 1440 Canal St, New Orleans, LA 70112, USA. ${ }^{3}$ School of Medicine, Virginia Commonwealth University, 1201 E Marshall St, Richmond, VA 23298, USA. ${ }^{4}$ Naval Medical Research Unit No. 6, Callao, Peru. ${ }^{5}$ Universidad Peruana Cayetano Heredia, Ave Honorio Delgado 430, Distrito de Lima, Peru. ${ }^{6}$ School of Public Health, University of Michigan, 1415 Washington Heights, Ann
Arbor, MI 48109, USA. ${ }^{7}$ Swiss Tropical and Public Health Institute, Socinstrasse 57, 4051 Basel, Switzerland. ${ }^{8}$ Bellevue, USA.

\section{Received: 30 August 2017 Accepted: 1 February 2018 \\ Published online: 12 February 2018}

\section{References}

1. Southworth J, Marsik M, Qiu Y, Perz S, Cumming G, Stevens F, et al. Roads as drivers of change: trajectories across the tri-National Frontier in MAP, the southwestern Amazon. Remote Sens. 2011;3:1047-66.

2. Salmón-Mulanovich G, Powell AR, Hartinger-Peña SM, Schwarz L, Bausch DG, Paz-Soldán VA. Community perceptions of health and rodent-borne diseases along the Inter-Oceanic Highway in Madre de Dios, Peru. BMC Public Health [Internet]. 2016 [cited 13 Oct 2016];16. Available from: http:// bmcpublichealth.biomedcentral.com/articles/10.1186/s12889-016-3420-3

3. Skeldon R. The evolution of migration patterns during urbanization in Peru | POPLINE.org. Am Geogr Soc. 1977;67:394-411.

4. Ramalho AA, Mantovani SA, Delfino BM, Pereira TM, Martins AC, Oliart-

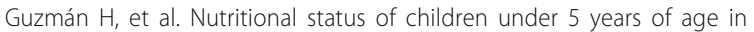
the Brazilian Western Amazon before and after the Interoceanic highway paving: a population-based study. BMC Public Health [Internet]. 2013 [cited 8 Nov 2016];13. Available from: http://bmcpublichealth.biomedcentral.com/ articles/10.1186/1471-2458-13-1098

5. Scullion JJ, Vogt KA, Sienkiewicz A, Gmur SJ, Trujillo C. Assessing the influence of land-cover change and conflicting land-use authorizations on ecosystem conversion on the forest frontier of Madre de Dios, Peru. Biol Conserv. 2014; 171:247-58.

6. Burroughs Pena MS, Bernabé-Ortiz A, Carrillo-Larco RM, Sánchez JF, Quispe R, Pillay TD, et al. Migration, urbanisation and mortality: 5-year longitudinal analysis of the PERU MIGRANT study. J Epidemiol Community Health. 2015; 69:715-8.

7. Harris JR, Todaro MP. Migration, Unemployment and Development: a two-sector analysis. Am Econ Rev. 1970;60:126-42.

8. Long LE. Migration and residential mobility in the United States. New York: Russell Sage Foundation; 1988

9. UN Commission on Human Rights Working Group of Intergovernmental Experts on the human rights of migrants (1st sess., 1997 : Geneva); UN. Commission on human rights. Report of the working Group of Intergovernmental Experts on the human rights of migrants submitted in accordance with commission on human rights resolution 1997/15 [internet]. Geneva: UN Commission on Human Rights; 1998 Mar. Available from: http://www. refworld.org/docid/3b00efd714.html. Accessed 5 Nov 2017.

10. Andersen GS, Kamper-Jørgensen Z, Carstensen B, Norredam M, Bygbjerg IC, Jørgensen ME. Diabetes among migrants in Denmark: incidence, mortality, and prevalence based on a longitudinal register study of the entire Danish population. Diabetes Res Clin Pract. 2016;122:9-16.

11. Borjas GJ, Bronars SG, Trejo SJ. Assimilation and the earnings of young internal migrants. Rev Econ Stat. 1992;74:170-5.

12. Hall M, Greenman E, Farkas G. Legal status and wage disparities for Mexican immigrants. Soc Forces. 2010;89:491-513.

13. Razuri H, Tokarz R, Ghersi BM, Salmon-Mulanovich G, Guezala MC, Albujar C, et al. Andes hantavirus variant in rodents, southern Amazon Basin, Peru. Emerg Infect Dis. 2014;20:257-60.

14. Goldberg TL. Forest fragmentation as cause of bacterial transmission among nonhuman primates, humans, and livestock, Uganda. Emerg Infect Dis. 2008;14:1375-82.

15. Miles MB, Huberman AM, Saldana J. Qualitative Data Analysis: A Methods Sourcebook. Thousand Oaks: SAGE Publications; 2013.

16. SocioCultural Research Consultants, LLC. Dedoose Version 7.0.23, web application for managing, analyzing, and presenting qualitative and mixed method research data [Internet]. Los Angeles, CA; 2016. Available from: www.dedoose.com. Accessed 4 Mar 2017.

17. Ashley C, Carney D. Sustainable livelihoods: lessons from early experience [internet]. 1999. Available from: http://www.the-eis.com/data/literature/ Sustainablelivelihoods_lessons\%20from\%20early\%20experience.pdf. Accessed 12 May 2017.

18. StataCorp. Stata Statistical Software: Release 14. College Station, TX: StataCorp LP: 2015.

19. Duc LT, Nguy $n$ T. How do children fare in the new millennium?: initial findings from Vietnam: round 3 survey report. Oxford: Young Lives, Department of International Development, University of Oxford; 2011. 
20. Trinies V, Garn JV, Chang HH, Freeman MC. The impact of a school-based water, sanitation, and hygiene program on absenteeism, Diarrhea, and respiratory infection: a matched-control trial in Mali. Am J Trop Med Hyg. 2016:94:1418-25.

21. Amarasinghe $U$, Samad M, Anputhas M. Spatial clustering of rural poverty and food insecurity in Sri Lanka. Food Policy. 2005;30:493-509.

22. Coveney J, O'Dwyer LA. Effects of mobility and location on food access. Health Place. 2009;15:45-55.

23. Loret de Mola C, Quispe R, Valle GA, Poterico JA. Nutritional Transition in Children under Five Years and Women of Reproductive Age: A 15-Years Trend Analysis in Peru. PLoS ONE [Internet]. 2014 [cited 19 May 2017];9. Available from: http://www.ncbi.nlm.nih.gov/pmc/articles/PMC3958518/

24. Yang H, Bain R, Bartram J, Gundry S, Pedley S, Wright J. Water safety and inequality in access to drinking-water between rich and poor households. Environ Sci Technol. 2013:47:1222-30.

25. Wright J, Gundry S, Conroy R. Household drinking water in developing countries: a systematic review of microbiological contamination between source and point-of-use. Tropical Med Int Health. 2004;9:106-17.

26. Cairncross S, Hunt C, Boisson S, Bostoen K, Curtis V, Fung IC, et al. Water, sanitation and hygiene for the prevention of diarrhoea. Int J Epidemiol. 2010;39:1193-205.

27. Reller ME, Mendoza CE, Lopez MB, Alvarez M, Hoekstra RM, Olson CA, et al. A randomized controlled trial of household-based FLOCCULANT-disinfectant drinking water treatment for Diarrhea prevention in rural GUATEMALA. Am. J. Trop. Med. Hyg. 2003;69:411-9.

28. Crump JA. Household based treatment of drinking water with flocculantdisinfectant for preventing diarrhoea in areas with turbid source water in rural western Kenya: cluster randomised controlled trial. BMJ. 2005;331:478-0.

29. Schmidt CM, Stilz A, Zimmermann KF. Mass migration, unions, and government intervention. J Public Econ. 1994;55:185-201.

30. Alston M. "You don't want to be a check-out chick all your life": the outmigration of young people from Australia's small rural towns. Aust J Soc Issues. 2004:39:299-313.

31. Murtazashvili I, Murtazashvili J. Can community-based land adjudication and registration improve household land tenure security? Evidence from Afghanistan. Land Use Policy. 2016;55:230-9.

32. Toulmin C. Securing land and property rights in sub-Saharan Africa: the role of local institutions. Land Use Policy. 2009;26:10-9.

\section{Submit your next manuscript to BioMed Central and we will help you at every step:}

- We accept pre-submission inquiries

- Our selector tool helps you to find the most relevant journal

- We provide round the clock customer support

- Convenient online submission

- Thorough peer review

- Inclusion in PubMed and all major indexing services

- Maximum visibility for your research

Submit your manuscript at www.biomedcentral.com/submit 